\title{
Efficacy of Natural Plant Products on the Control of Aggregate Sheath Spot of Rice
}

\author{
Patcharavipa Chaijuckam and R. Michael Davis, Department of Plant Pathology, University of California, Davis \\ 95616
}

\begin{abstract}
Chaijuckam, P., and Davis, R. M. 2010. Efficacy of natural plant products on the control of aggregate sheath spot of rice. Plant Dis. 94:986-992.

Aqueous extracts from ginger, pepper, basil, and garlic plants and essential oils from neem, garlic, lemongrass, and cinnamon were evaluated for their antagonistic effects against Rhizoctonia oryzae-sativae, the cause of aggregate sheath spot of rice. The compounds in $5 \%$ concentrations in water or agar were tested on several $R$. oryzae-sativae isolates. Cinnamon oil, the most efficacious plant product in vitro, was further tested in the greenhouse for the control of the disease on two rice cultivars inoculated with $R$. oryzae-sativae. One milliliter of each of four cinnamon oil concentrations $(12.5,37.5,62.5$, or $87.5 \%)$ diluted in vegetable oil was applied to the surface of the water in constantly flooded pots. Cinnamon oil failed to reduce the disease caused by one of the isolates at any concentration. Cinnamon oil suppressed the disease caused by the other isolate on one of the cultivars at a concentration of $37.5 \%$, and on both cultivars at a concentration of 62.5 and $87.5 \%$. However, cinnamon oil at $87.5 \%$ was phytotoxic. Cinnamon oil has potential to control aggregate sheath spot but relatively high concentrations were required for disease suppression.
\end{abstract}

Rhizoctonia oryzae-sativae, the cause of aggregate sheath spot disease on rice (Oryza sativa L.), occurs in California in the United States and in countries including Japan, China, Vietnam, India, Thailand, Iran, Venezuela, Uruguay, and Australia $(4,9,19,20,33)$. Aggregate sheath spot became an important disease in California after susceptible semidwarf, high-yielding cultivars were introduced and widely grown (10). Disease symptoms are characterized by oval lesions with green or gray centers surrounded by a distinct brown margin. Several lesions can occur together, resulting in an aggregation of lesions. The fungus also attacks panicles, which results in discolored grain $(9,10,23)$. Overwintering sclerotia or mycelia in soil or crop residue serve as reservoirs of inocula $(9,10,21,23,25)$. A subsequent rice crop is infected by floating sclerotia in the rice paddy $(9,10,23)$. Aggregate sheath spot caused yield losses of $20 \%$ in Australia (18) and 4 to $9 \%$ in Uruguay (20). However, significant yield losses have not been documented in California (11).

Corresponding author: R. M. Davis

E-mail: rmdavis@ucdavis.edu

Current address of P. Chaijuckam: Department of Plant Pathology, Kasetsart University, Kampaeng Saen Campus, Nakhon Pathom, 73140 Thailand.

Accepted for publication 8 April 2010.

doi:10.1094/PDIS-94-8-0986

(c) 2010 The American Phytopathological Society
Organic rice growers have relatively few options for the management of aggregate sheath spot. Currently, all rice cultivars grown in California are susceptible to aggregate sheath spot at some level (23). Although removing and destroying crop residues is a somewhat effective strategy for managing the disease, applications of the fungicide azoxystrobin are recommended in conventionally grown crops when the disease is severe (i.e., when lesions spread to the flag leaf; 40). Alternative disease control options that may benefit organic rice growers include application of natural plant products, which have been used in other organic crop systems (5). Plant extracts and plant oils with antifungal activity against a variety of fungi have been reported. For example, Wilson et al. (42) found that garlic extracts, pepper extracts, and essential oils of palmarosa, red thyme, and cinnamon leaf had high antifungal activity against Botrytis cinerea. Garlic oil inhibited growth and sclerotium formation of $R$. solani (36). Lemongrass oil has antimicrobial activity against $R$. solani, Sclerotium rolfsii, and Sclerotinia sclerotiorum (13). Advantages of natural plant products include the ease with which they biodegrade and their frequently systemic nature (15). Oil products also float on water, which would allow direct contact with the floating sclerotia of $R$. oryzae-sativae. This would increase the opportunity of oil products to penetrate and react directly with floating sclerotia before infection.

The objectives of this research were to determine the ability of various plant extracts and essential oils to inhibit vegeta- tive growth, sclerotia production, and sclerotia germination of $R$. oryzae-sativae and the efficacy of cinnamon oil to control $R$. oryzae-sativae under greenhouse conditions.

\section{MATERIALS AND METHODS}

Plant product preparation. Extracts from ginger, pepper, basil, and garlic plants and plant essential oils, including neem, garlic, lemongrass, and cinnamon (leaf) oils, were used in this study. For plant extracts, $150 \mathrm{~g}$ of ginger rhizomes, pepper fruit, basil leaves, or garlic cloves from a retail grocery store were washed with distilled water and macerated in 150 $\mathrm{ml}$ of sterile water. The suspensions were then filtered through two layers of Miracloth (Calbiochem, Gibbstown, NJ) followed by serial passage through 1.6- $\mu \mathrm{m}$ GF/A filter paper (Whatman, Florham Park, NJ), 0.8- and $0.45-\mu \mathrm{m}$ filter membranes, and a $0.22-\mu \mathrm{m}$ filter membrane under vacuum. Plant essential oils obtained from the manufacturer (Cosmic Living Inc., Naperville, IL) were sterilized by passage through a $0.22-\mu \mathrm{m}$ filter.

Antifungal activity assay. About $20 \mathrm{ml}$ of each plant extract diluted to $5 \%$ in potato dextrose agar (PDA) was poured into sterile 9-mm-diameter petri plates. PDA with sterile water served as the control. Agar plates with plant essential oils were prepared according to the modified method of Banerjee et al. (1). Tween-20 (1 ml) was mixed with $49 \mathrm{ml}$ of water and then sterilized by passage through a $0.22-\mu \mathrm{m}$ filter. In all, $50 \mathrm{ml}$ of each plant essential oil was emulsified with this sterile Tween-20 solution and vigorously mixed with $900 \mathrm{ml}$ of PDA. About $20 \mathrm{ml}$ of the mixture was then poured into a sterile petri plate. PDA with $0.1 \%$ Tween-20 served as the control. Eleven isolates of $R$. oryzae-sativae from California rice fields were grown for 5 days on PDA and a 4-mm-diameter mycelial disc of each isolate was transferred to each of four replicate agar plates containing the plant products. Radial growth of $R$. oryzae-sativae was recorded after 3 days at room temperature (approximately $25^{\circ} \mathrm{C}$ ). The production of sclerotia was rated after 7 days based on the following scale: $0=$ no sclerotia production and $1=$ sclerotia covering less than $25 \%, 2=25$ to $50 \%, 3=50$ to $75 \%$, and $4=$ more than $75 \%$ of the petri plate surface. There were four replicate plates per isolate per plant product in each of two independent trials. 
Inhibition of sclerotia germination was determined by a modified method of Banerjee et al. (1). Ten sclerotia, harvested from each of $11 R$. oryzae-sativae isolates grown on PDA for 14 days, were transferred to PDA after the sclerotia were soaked for $10 \mathrm{~min}$ in each $5 \%$ plant extract in sterile water or each $5 \%$ plant essential oil in a sterile aqueous solution of $0.1 \%$ Tween-20. After incubation at room temperature for 3 days, the number of germinated sclerotia was counted. Sclerotia soaked in sterile water or $0.1 \%$ Tween-20 served as controls. The experiment was repeated once with four replicate plates in each trial.

$L_{50}$ and exposure time. The $\mathrm{LD}_{50}$ of lemongrass oil and cinnamon oil were determined. Ten sclerotia, harvested from each of seven 14-day-old $R$. oryzae-sativae isolates, were soaked for $10 \mathrm{~min}$ in $5,0.5$, 0.05 , and $0.005 \%$ concentrations of each oil. Treated sclerotia were transferred to PDA and the number of germinated sclerotia was counted after 3 days. There were four replicates per isolate in each of two independent trials. The exposure time of cinnamon oil to kill three $R$. oryzae-sativae isolates was determined by exposing sclerotia to $0.5 \%$ cinnamon oil for $10,20,40$, and $80 \mathrm{~min}$.

Greenhouse assay. The ability of cinnamon oil to control aggregate sheath spot was evaluated in a greenhouse maintained at 21 to $32^{\circ} \mathrm{C}$. There were two greenhouse assays: the objective of the first experiment was to estimate effective cinnamon oil concentrations and the second experiment was conducted based on the results of the first experiment. Treatments were replicated four times in a completely randomized design and both experiments were repeated once.

In the first experiment, treatments were no oil, $1 \mathrm{ml}$ of vegetable oil but no cinnamon oil (control), and $1 \mathrm{ml}$ of $12.5 \%$ ( $0.125 \mathrm{ml}$ of cinnamon oil $/ \mathrm{pot})$ or $87.5 \%$ ( $0.875 \mathrm{ml}$ of cinnamon oil/pot) cinnamon oil diluted with vegetable oil (a generic soybean-based oil from a local market). Two rice cultivars (M-205 and M-206), two $R$. oryzae-sativae isolates (3B and 13B), and a noninoculated control were included in all experiments, for a total of 24 treatment combinations. Three-week-old rice seedlings were transplanted into $25 \mathrm{~cm}$ diameter pots containing a sterilized potting mix of $50 \%$ sphagnum peat moss, $50 \%$ washed sand, and dolomite lime at 2.43 $\mathrm{kg} / \mathrm{m}^{3}$, oyster shell lime at $0.872 \mathrm{~kg} / \mathrm{m}^{3}$, superphosphate at $0.872 \mathrm{~kg} / \mathrm{m}^{3}$, calcium nitrate at $0.344 \mathrm{~kg} / \mathrm{m}^{3}$, potassium nitrate at $135 \mathrm{ml} / \mathrm{m}^{3}$, and potassium sulfate at 90 $\mathrm{ml} / \mathrm{m}^{3}$. Five seedlings were transplanted per pot. Potting mix was added into the pots 8 $\mathrm{cm}$ from the bottom and the water level was maintained $6 \mathrm{~cm}$ from the top of the pot and $8 \mathrm{~cm}$ above the potting mix surface.

Four weeks after transplanting, $0.25 \mathrm{~g}$ of sclerotia of $R$. oryzae-sativae, which floated on the water surface, were added to each pot. Inoculum preparation was modified from the procedure described by Gunnell and Webster (12). Briefly, unhulled rice and rice hulls were mixed in a ratio of $10: 1$ ( $\mathrm{vol} / \mathrm{vol})$ and $350 \mathrm{ml}$ of the rice mixture was then added to a 1-liter bottle. The center of the lid was removed and replaced with two layers of filter paper (Whatman mo. 1). After $35 \mathrm{ml}$ of distilled water was added to each bottle, the bottles were autoclaved twice at $121^{\circ} \mathrm{C}$ for 90 min with a 24-h interval. Sterile water $(100 \mathrm{ml})$ was added in each bottle and mixed with the rice mixture. Five $1.5-\mathrm{cm}$-diameter agar plugs of a 7-day-old $R$. oryzae-sativae culture were then added to each bottle. The cultures were incubated at room temperature for 1 month and periodically shaken. After the colonized rice grains were air dried, sclerotia were sieved from the grain and stored at $6^{\circ} \mathrm{C}$ for 1 day before inoculation. Treatments were applied on the water surface with a pipette 1 day after sclerotia were added. Beginning at 2 weeks after inoculation, the length of the longest lesion on each rice plant was recorded weekly for 3 weeks. At the end of the experiment ( 8 weeks after inoculation), rice plants were air dried and the dry weight of the plants aboveground in each pot was determined.

Based on the results of the first experiment, the second experiment was conducted only with isolate $3 \mathrm{~B}$ with four oil treatments. Treatments included no oil, 1 $\mathrm{ml}$ of vegetable oil but no cinnamon oil (control), and $1 \mathrm{ml}$ of $37.5 \%(0.375 \mathrm{ml}$ of cinnamon oil $/ \mathrm{pot})$ or $62.5 \%(0.625 \mathrm{ml}$ of cinnamon oil/pot) cinnamon oil. Cinnamon oil at $87.5 \%$ was not used because it was phytotoxic in the first experiment. The length of the longest lesion on each rice plant and the plant dry weights were recorded as above.

Data analyses. All statistical analyses were performed by JMP (version 7.0; SAS Institute Inc., Cary, NC). Because the results from both trials were consistent and there were no interactions between trials and treatments, data from both trials were combined and analyzed together. The differences in vegetative growth and sclerotia germination between the treatments with plant products and the controls were tested by paired $t$ test because the same source of inocula was used. The effect of the plant products on sclerotia production was analyzed by ordinal logistic model. Bonferroni correction was employed for multiple pairwise comparisons to limit type I error. Treatments with no response on vegetative growth, sclerotia production, or sclerotia germination were excluded from statistical analyses.

The $\mathrm{LD}_{50}$ of cinnamon oil on killing sclerotia was estimated by regression fitting of the percent kill of sclerotia from each $R$. oryzae-sativae isolate and the natural logarithm of the concentrations of each plant essential oil. The difference of the $\mathrm{LD}_{50} \mathrm{~s}$ between lemongrass oil and cinnamon oil for the seven $R$. oryzaesativae isolates was assessed by Student's $t$ test. The exposure time was estimated by regression fitting of the percent kill of sclerotia from each of three $R$. oryzaesativae isolates and the natural logarithm of different exposure times to $0.5 \%$ cinnamon oil.

Disease severity was analyzed by repeated measures in multivariate analysis of variance. The canonical scores of the main effects were generated and subjected to the Tukey-Kramer highly significant difference (HSD) test for mean comparisons. Each pot was treated as a replicate and each plant was a subsample. Because there were no interactions between trials and cinnamon oil treatments, data from both trials were combined and trial was treated as a block term. Plant dry weights were analyzed by analysis of variance and compared among treatments by the TukeyKramer HSD method.

\section{RESULTS}

Garlic extract and all plant essential oils except neem oil completely inhibited vegetative growth and, therefore, sclerotia production of $R$. oryzae-sativae (Table 1 ). The effect of neem oil was highly significant and resulted in a reduction in mycelial growth and a reduction in sclerotia production compared with the control. In contrast, three plant extracts, ginger, pepper, and basil, significantly increased vegetative growth of $R$. oryzae-sativae. Pepper and basil extracts increased sclerotia production but the ginger extract had no effect. None of the plant extracts suppressed sclerotia germination. In contrast, there was no germination of sclerotia treated with lemongrass oil or cinnamon oil. Neem oil and garlic oil significantly decreased sclerotia germination.

Because lemongrass oil and cinnamon oil completely inhibited vegetative growth, sclerotia production, and sclerotia germination of $R$. oryzae-sativae, the $\mathrm{LD}_{50}$ of each was determined. The $\mathrm{LD}_{50}$ of each $R$. oryzae-sativae isolate was estimated from regression fitting of the percent kill of sclerotia and the natural logarithm of the plant essential oil concentrations (Fig. 1). The average $\mathrm{LD}_{50}$ of lemongrass oil $(1.49 \%)$ was significantly higher than the average $\mathrm{LD}_{50}$ of cinnamon oil $(0.34 \%)$ (Table 2).

There was a significant quadratic polynomial relationship between sclerotia mortality and exposure time to $0.5 \%$ cinnamon oil for isolates $11 \mathrm{~A}$ and $12 \mathrm{~B}$ but not isolate 14A (Table 3; Fig. 2). However, because the regression curves of all three isolates were not significantly different $(P=$ 0.0723), a general regression fitting model from combined data for $R$. oryzae-sativae was determined. In general, there was also a significant quadratic polynomial relationship between the percent kill of scle- 
rotia and exposure time to $0.5 \%$ cinnamon oil (Table 3; Fig. 3). Based on the general model, a population of sclerotia would be completely killed after 32 min of exposure to $0.5 \%$ cinnamon oil.

In the first greenhouse experiment, there were significant interactions between cinnamon oil concentration and cultivars $(P=$ $0.0022)$ and isolates $(P=0.0155)$; there- fore, the results were interpreted separately. Vegetable oil without cinnamon oil had no effect on the disease of either cultivar (Table 4). No concentration of cinnamon oil inhibited disease caused by isolate 13B relative to the vegetable oil control. Relative to the vegetable oil control, disease severity of plants inoculated with isolate $3 \mathrm{~B}$ was reduced by $87.5 \%$ cinna-

Table 1. Antifungal activity of $5 \%$ ( $\mathrm{vol} / \mathrm{vol})$ plant products on mean vegetative growth, sclerotia production, and sclerotia germination on 11 Rhizoctonia oryzae-sativae isolates ${ }^{\mathrm{u}}$

\begin{tabular}{|c|c|c|c|}
\hline Plant products & $\begin{array}{c}\text { Colony diameter } \\
(\mathbf{c m})^{\mathbf{v}, \mathbf{w}}\end{array}$ & $\begin{array}{c}\text { Sclerotia production } \\
\text { rating }^{x}\end{array}$ & $\begin{array}{l}\text { Germinated sclerotia } \\
\text { per } 10 \text { sclerotia }\end{array}$ \\
\hline \multicolumn{4}{|l|}{ Extracts } \\
\hline Control (water) & 5.29 & 2.1 & 9.6 \\
\hline Ginger & $5.46^{* * * *}$ & 2.1 & 9.4 \\
\hline Pepper & $5.63 * * *$ & $3.3 * * *$ & 9.3 \\
\hline Basil & $5.96 * * *$ & $2.9 * * *$ & 9.5 \\
\hline Garlic $^{z}$ & 0.00 & $\ldots$ & 9.4 \\
\hline \multicolumn{4}{|l|}{ Essential oils } \\
\hline Control $(0.1 \%$ Tween- 20$)$ & 4.65 & 1.5 & 9.9 \\
\hline Neem oil & $1.87 * * *$ & $0.1 * * *$ & $6.9 * * *$ \\
\hline Garlic oil $^{\mathrm{z}}$ & 0.00 & $\ldots$ & $6.1 * * *$ \\
\hline Lemongrass oil ${ }^{\mathrm{z}}$ & 0.00 & $\ldots$ & 0.0 \\
\hline Cinnamon oil ${ }^{\mathrm{Z}}$ & 0.00 & $\ldots$ & 0.0 \\
\hline
\end{tabular}

"Significant difference between plant products and the controls at $P \leq 0.05,0.01$, and 0.001 is indicated by *,**, and ***, respectively; means from combined data of two trials with four replicates in each trial.

${ }^{v}$ Radial growth of $R$. oryzae-sativae on potato dextrose agar (PDA) after 3 days.

${ }^{\mathrm{w}}$ Differences between the mean of plant products and the controls were analyzed by paired $t$ test.

${ }^{x}$ Production of sclerotia was estimated at 7 days based on the following scale: $0=$ no sclerotia production and $1=$ sclerotia produced on less than $25 \%, 2=25$ to $50 \%, 3=50$ to $75 \%$, and $4=$ more than $75 \%$ of the petri plate surface. Differences between the mean of plant products and the controls were analyzed by ordinal logistic model; ... indicates that sclerotia production was not evaluated because there was no vegetative growth for those treatments.

${ }^{y}$ Sclerotia were soaked in each 5\% plant extract or oil for $10 \mathrm{~min}$ and incubated on PDA for 3 days.

${ }^{\mathrm{z}}$ Treatments with no response on vegetative growth, sclerotia production, or sclerotia germination were excluded from statistical analyses.

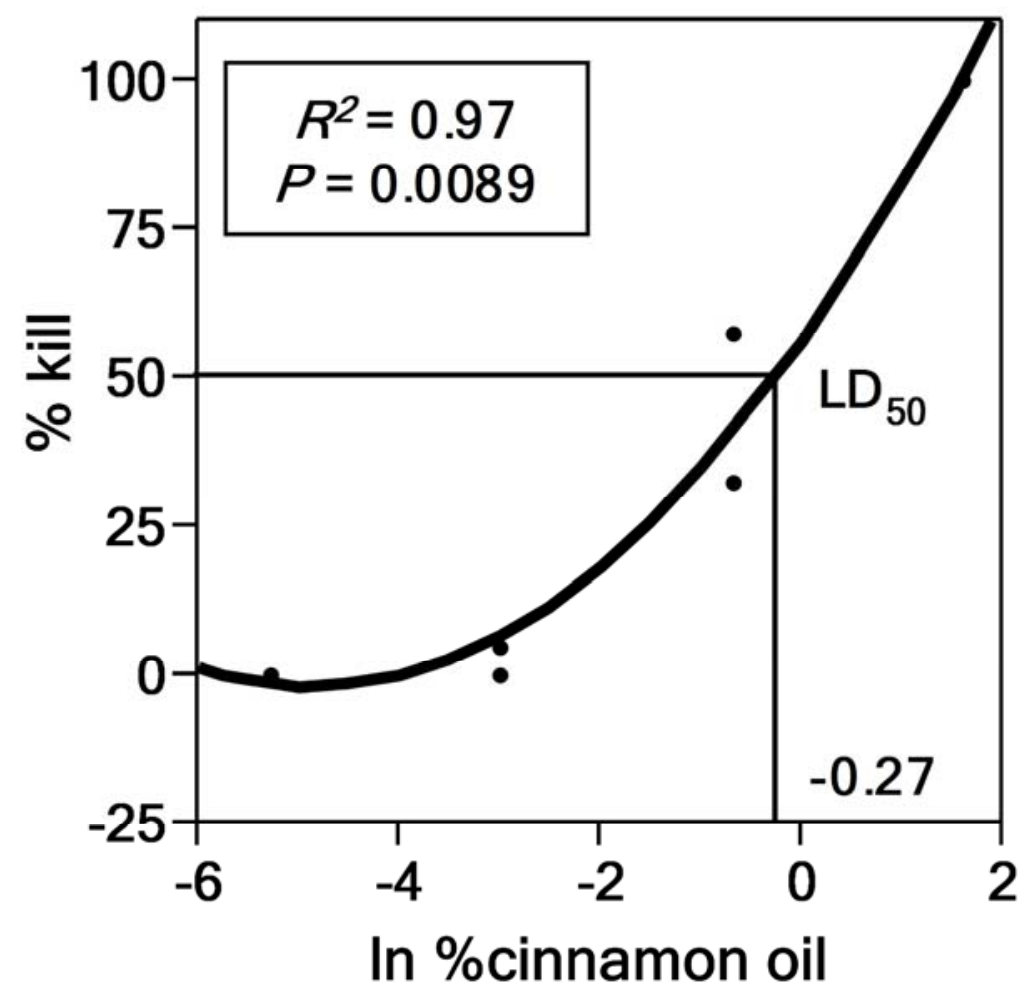

Fig. 1. Regression fitting of the percent kill of sclerotia and the natural logarithm (ln) of cinnamon oil concentrations to determine $\mathrm{LD}_{50}$ of cinnamon oil against Rhizoctonia oryzae-sativae isolate $11 \mathrm{~A}$.

mon oil but not at the concentration of $12.5 \%$. Disease severity caused by either isolate was higher in cv. M-205 than M$206(P<0.0001)$. In general, neither the controls (vegetable oil) nor $12.5 \%$ cinnamon oil reduced rice dry weights (Table 4). However, $87.5 \%$ cinnamon oil significantly reduced plant weight relative to the controls, and chlorotic stripes on the leaf sheaths of some tillers developed.

In the second greenhouse experiment, there was also a significant interaction between cinnamon oil concentration and cultivars $(P=0.0456)$; therefore, the results were interpreted separately in each cultivar. Vegetable oil without cinnamon oil had no effect on lesion expansion caused by isolate 3B (Table 5). Cinnamon oil at $62.5 \%$ reduced disease severity of isolate $3 \mathrm{~B}$ in both cultivars compared with the control. The $37.5 \%$ cinnamon oil, however, suppressed lesion expansion only in M-206. Lesion expansion by isolate 3B was greater in cv. M-205 than M-206 $(P<$ 0.0001). For both cultivars, rice dry weights were not affected by either concentration of cinnamon oil (Table 5).

\section{DISCUSSION}

In general, plant essential oils were more active against $R$. oryzae-sativae than plant extracts. All plant essential oils and the garlic extract had antifungal activity with different degrees of intensity. Lemongrass oil and cinnamon oil were the most efficacious plant products because they completely inhibited vegetative growth, sclerotia production, and sclerotia germination of $R$. oryzae-sativae. The greater activity of cinnamon oil $\left(\mathrm{LD}_{50}=0.34 \%\right)$ against $R$. oryzae-sativae relative to lemongrass oil $\left(\mathrm{LD}_{50}=1.49 \%\right)$ was similar to a report on the relative activity of cinna-

Table 2. $\mathrm{LD}_{50}$ of lemongrass and cinnamon oils on killing sclerotia of seven Rhizoctonia oryzaesativae isolates ${ }^{\mathrm{y}}$

\begin{tabular}{lcc}
\hline & \multicolumn{2}{c}{$\mathbf{L D}_{\mathbf{5 0}}(\%)$} \\
\cline { 2 - 3 } Isolate & Lemongrass oil & Cinnamon oil \\
\hline 3B & 1.62 & 0.14 \\
11A & 1.63 & 0.76 \\
12B & 1.55 & 0.69 \\
13B & 1.61 & 0.16 \\
14A & 1.63 & 0.31 \\
16A & 1.18 & 0.16 \\
17B & 1.23 & 0.17 \\
Mean $^{\mathrm{z}}$ & 1.49 & 0.34 \\
\hline
\end{tabular}

${ }^{y}$ Sclerotia were soaked for $10 \mathrm{~min}$ in $5,0.5$, 0.05 , and $0.005 \%$ concentrations of lemongrass oil or cinnamon oil. The $\mathrm{LD}_{50}$ of each $R$. oryzae-sativae isolate was derived from regression fitting of percent kill of sclerotia from each $R$. oryzae-sativae and natural logarithm of plant essential oil concentrations with combined data from two trials.

${ }^{\mathrm{z}}$ Mean $\mathrm{LD}_{50}$ of seven $R$. oryzae-sativae isolates for each plant essential oil. There was a significant difference of $\mathrm{LD}_{50} \mathrm{~s}$ between lemongrass oil and cinnamon oil $(P<0.0001)$ assessed by Student's $t$ test. 
mon and lemongrass oils against $B$. cinerea (42) and Fusarium proliferatum (39). The major chemical constituent in cinnamon (leaf) oil is eugenal (34); in lemongrass oil, the major constituents are limonene (42) and citral (30). At a concentration of $1 \%$, eugenal, limonene, and citral were antagonistic to Cercospora arachidicola, Phaeoisariopsis personata, and Puccinia arachidis (16). These components may potentially contribute to the antifungal activity against $R$. oryzaesativae.

Both garlic extract and garlic oil completely inhibited growth and sclerotia production of $R$. oryzae-sativae but only garlic oil significantly reduced sclerotia germination. Garlic oil also inhibited growth and sclerotium formation by $R$. solani (36). The other materials (neem oil, ginger, pepper, and basil) either had little effect on $R$. oryzae-sativae or increased its growth. In contrast, a $10 \%$ dilution of garlic and pepper extracts exhibited greatest inhibition of vegetative growth and spore germination of $B$. cinerea among 345 plant extracts (42).

The sensitivity of fungi and even isolates of the same species to plant extracts and essential oils may vary. For example, neem oil partially suppressed sclerotia germination of California isolates of $R$. oryzae-sativae in this study but completely inhibited sclerotia germination of $R$. oryzae-sativae from India (1). In the current study, cinnamon oil reduced aggregate sheath spot caused by one isolate of $R$. oryzae-sativae but not another. Sensitivity to cinnamon oil may be genetically influenced because isolate $3 \mathrm{~B}$ and $13 \mathrm{~B}$ are in distinct somatic compatibility groups ( $\mathrm{P}$. Chaijuckam and R. M. Davis, unpublished data).

In this study, cinnamon oil was applied within $24 \mathrm{~h}$ after sclerotia of $R$. oryzaesativae were added to the pots to mimic a natural pathosystem. In a field, sclerotia would be present before an application of any kind of fungicide could be made. Vegetable oil was used to dilute cinnamon oil in this study because it was documented as a good floating and spreading agent for fungicides active against $R$. solani in rice (27). In general, vegetable oil had no effect on disease severity and rice growth. Cinnamon oil at a concentration of $12.5 \%$ did not decrease aggregate sheath spot and $32.5 \%$ cinnamon oil was only effective on one rice cultivar, M-206, which was less susceptible to $R$. oryzaesativae than M-205. Thus, a lower concentration of cinnamon oil may offer some disease control in a cultivar partially resistant to $R$. oryzae-sativae. At a concentration of $87.5 \%$, cinnamon oil decreased disease development but was phytotoxic because rice plant weight was reduced and chlorotic stripes on the leaf sheaths of some tillers developed. The optimal concentration of cinnamon oil to reduce lesion expansion caused by $R$. oryzae-sativae in this study was $62.5 \%$ because it was effective in both cultivars and had no effect on rice dry weight. A relatively high rate of cinnamon oil was apparently required because sclerotia are thick-walled structures able to resist unfavorable environments (40).

Although cinnamon oil completely inhibited vegetative growth, sclerotia production, and sclerotia germination of $R$. oryzae-sativae in vitro, the disease was not completely controlled in vivo. Many factors may have influenced these results. For the experiment in vitro, the temperature was a constant $25^{\circ} \mathrm{C}$ and the surface area of an agar plate was small. Therefore, the cinnamon oil was stable and came into direct contact with the sclerotia. In the greenhouse experiment, temperatures fluctuated between 21 and $32^{\circ} \mathrm{C}$ and sunlight may have degraded the oil.

In other studies, cinnamon oil suppressed Phytophthora blight and reduced population densities of Phytophthora nicotianae (3). Cinnamon oil also inhibited spore germination of Phaeoisariopsis personata and mycelial growth of Aspergillus niger and reduced late leaf spot and crown rot of peanut (16). Furthermore, there are several other reports of the antagonistic properties of cinnamon oil to plantpathogenic fungi $(34,42)$, bacteria (8), and nematodes (17). In addition, cinnamon oil inhibited mycotoxin production of $A$. flavus (31), repelled insects from bean seed (28), and had insecticidal activity against

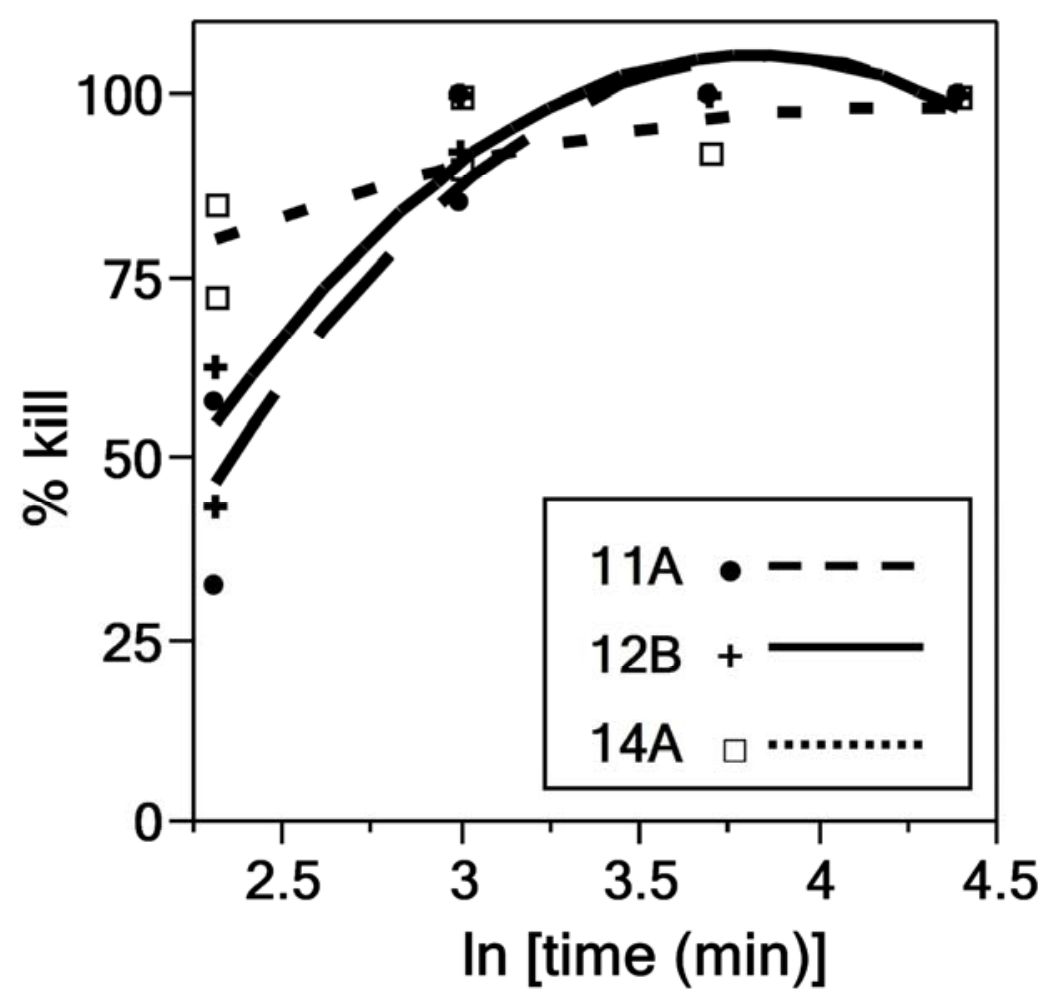

Fig. 2. Regression fitting of the percent kill of sclerotia and the natural logarithm (ln) of exposure times at $0.5 \%$ cinnamon oil on three Rhizoctonia oryzae-sativae isolates.

Table 3. Regression models of the exposure time of sclerotia of three Rhizoctonia oryzae-sativae isolates to $0.5 \%$ cinnamon oil ${ }^{\mathrm{w}}$

\begin{tabular}{|c|c|c|c|c|}
\hline Isolate & Regression model $^{x}$ & $R^{2}$ & $\mathbf{S E}^{\mathbf{y}}$ & $\boldsymbol{P}$ \\
\hline $11 \mathrm{~A}$ & $\%$ kill $=16.04+24.89 \ln$ time $-24.72(\ln \text { time }-3.34)^{2}$ & 0.89 & 7.58 & 0.0224 \\
\hline $12 \mathrm{~B}$ & $\%$ kill $=31.09+20.86 \ln$ time $-22.48(\text { ln time }-3.34)^{2}$ & 0.90 & 6.02 & 0.0135 \\
\hline 14A & $\%$ kill $=64.76+8.84 \ln$ time $-4.55(\ln \text { time }-3.34)^{2}$ & 0.66 & 4.78 & 0.3844 \\
\hline Combined $^{\mathrm{z}}$ & $\%$ kill $=37.30+18.20 \ln$ time $-17.25(\ln \text { time }-3.34)^{2}$ & 0.73 & 4.55 & 0.0011 \\
\hline
\end{tabular}

${ }^{\mathrm{w}}$ Sclerotia were soaked in $0.5 \%$ cinnamon oil for $10,20,40$, and $80 \mathrm{~min}$.

${ }^{x}$ Regression curve of each $R$. oryzae-sativae isolate was derived from regression fitting of percent kill of $R$. oryzae-sativae sclerotia and natural logarithm of different exposure times at $0.5 \%$ cinnamon oil with combined data from two trials.

y Standard error.

${ }^{\mathrm{z}}$ Regression curves of all three isolates were not significantly different $(P=0.0723)$; therefore, data were combined. 


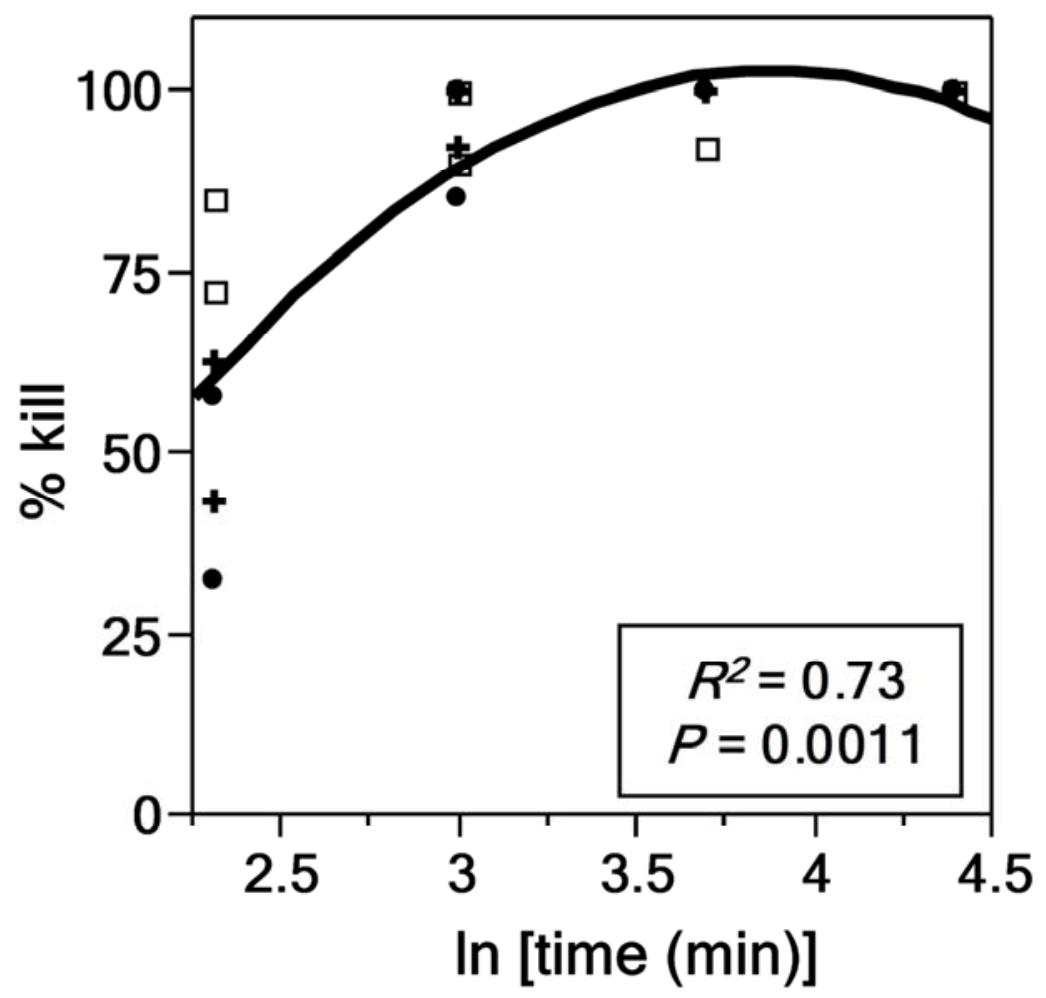

Fig. 3. Regression fitting of the percent kill of sclerotia and the natural logarithm (ln) of exposure times at $0.5 \%$ cinnamon oil on the combined data from three Rhizoctonia oryzae-sativae isolates.

Table 4. Effect of cinnamon oil treatments on disease severity and plant dry weight of two rice cultivars and two Rhizoctonia oryzae-sativae isolates (first greenhouse experiment)

\begin{tabular}{|c|c|c|c|c|c|c|}
\hline \multirow[b]{2}{*}{ Cultivar, isolate } & \multirow[b]{2}{*}{ Treatment $^{\mathrm{x}}$} & \multicolumn{3}{|c|}{ Mean of lesion length $(\mathrm{cm})^{\mathrm{w}}$} & \multirow[b]{2}{*}{ Scores $^{\mathrm{y}}$} & \multirow[b]{2}{*}{ Dry weight $(g)^{z}$} \\
\hline & & 2 weeks & 3 weeks & 4 weeks & & \\
\hline \multicolumn{7}{|l|}{ M-205 } \\
\hline \multirow[t]{4}{*}{$3 \mathrm{~B}$} & No oil & 3.45 & 6.39 & 7.71 & $0.64 \mathrm{a}$ & $34.25 \mathrm{ab}$ \\
\hline & Control & 3.55 & 5.59 & 7.14 & $0.60 \mathrm{ab}$ & $36.29 \mathrm{a}$ \\
\hline & $12.5 \%$ & 2.11 & 4.25 & 5.66 & $0.44 \mathrm{bc}$ & $33.98 \mathrm{ab}$ \\
\hline & $87.5 \%$ & 1.33 & 2.78 & 4.91 & $0.33 \mathrm{c}$ & $28.70 \mathrm{~b}$ \\
\hline \multirow[t]{4}{*}{$13 \mathrm{~B}$} & No oil & 3.45 & 5.47 & 7.19 & $0.59 \mathrm{a}$ & $34.18 \mathrm{ab}$ \\
\hline & Control & 2.39 & 4.55 & 5.95 & $0.47 \mathrm{ab}$ & $36.40 \mathrm{a}$ \\
\hline & $12.5 \%$ & 1.71 & 2.99 & 4.61 & $0.34 \mathrm{~b}$ & $33.53 \mathrm{ab}$ \\
\hline & $87.5 \%$ & 1.88 & 3.71 & 4.54 & $0.37 \mathrm{~b}$ & $31.33 \mathrm{~b}$ \\
\hline \multirow[t]{4}{*}{ Noninoculated } & No oil & $\ldots$ & $\ldots$ & $\ldots$ & $\ldots$ & $44.75 \mathrm{a}$ \\
\hline & Control & $\ldots$ & $\ldots$ & $\ldots$ & $\ldots$ & $36.14 \mathrm{bc}$ \\
\hline & $12.5 \%$ & $\ldots$ & $\ldots$ & $\ldots$ & $\ldots$ & $37.13 \mathrm{ab}$ \\
\hline & $87.5 \%$ & $\ldots$ & $\ldots$ & $\ldots$ & $\ldots$ & $30.39 \mathrm{c}$ \\
\hline \multicolumn{7}{|l|}{ M-206 } \\
\hline \multirow[t]{4}{*}{$3 \mathrm{~B}$} & No oil & 0.97 & 2.54 & 5.32 & $0.32 \mathrm{ab}$ & $35.08 \mathrm{ab}$ \\
\hline & Control & 2.23 & 4.40 & 5.53 & $0.44 \mathrm{a}$ & $39.93 \mathrm{a}$ \\
\hline & $12.5 \%$ & 1.56 & 2.98 & 4.10 & $0.32 \mathrm{ab}$ & $38.86 \mathrm{a}$ \\
\hline & $87.5 \%$ & 1.31 & 2.35 & 3.78 & $0.27 \mathrm{~b}$ & $30.19 \mathrm{~b}$ \\
\hline \multirow[t]{4}{*}{$13 \mathrm{~B}$} & No oil & 1.74 & 3.77 & 4.52 & $0.37 \mathrm{a}$ & $37.30 \mathrm{a}$ \\
\hline & Control & 1.09 & 2.14 & 4.15 & $0.27 \mathrm{ab}$ & $38.91 \mathrm{a}$ \\
\hline & $12.5 \%$ & 1.51 & 2.71 & 4.09 & $0.31 \mathrm{ab}$ & $36.56 \mathrm{a}$ \\
\hline & $87.5 \%$ & 1.10 & 1.84 & 3.01 & $0.22 \mathrm{~b}$ & $28.78 \mathrm{~b}$ \\
\hline \multirow[t]{4}{*}{ Noninoculated } & No oil & $\ldots$ & $\ldots$ & $\ldots$ & $\ldots$ & $40.93 \mathrm{a}$ \\
\hline & Control & $\ldots$ & $\ldots$ & $\ldots$ & $\ldots$ & $41.43 \mathrm{a}$ \\
\hline & $12.5 \%$ & $\ldots$ & $\ldots$ & $\ldots$ & $\ldots$ & $40.14 \mathrm{a}$ \\
\hline & $87.5 \%$ & $\ldots$ & $\ldots$ & $\ldots$ & $\ldots$ & $32.81 \mathrm{~b}$ \\
\hline
\end{tabular}

${ }^{v}$ Within each cultivar and each $R$. oryzae-sativae isolate, means in the same column followed by the same letter are not significantly different at $\alpha=0.05$ according to the Tukey-Kramer highly significant difference test.

${ }^{\text {w }}$ Length of the longest lesion of each rice plant was recorded weekly for 3 weeks (2, 3, and 4 weeks after inoculation).

${ }^{x}$ Four cinnamon oil treatments were no oil, $1 \mathrm{ml}$ of vegetable oil but no cinnamon oil (control), $1 \mathrm{ml}$ of $12.5 \%$ cinnamon oil, and $1 \mathrm{ml}$ of $87.5 \%$ cinnamon oil.

y Canonical scores were calculated from lesion length data by repeated measures in multivariate analysis of variance procedure (32).

z Aboveground. the rice weevil (22). Cinnamon oil is likely a broad-spectrum compound against many pests. In addition to fungi, rice can be damaged by bacteria, nematodes, viruses, and insects (41). Thus, cinnamon oil could benefit rice growers by managing several pests.

Natural plant products may reduce disease development by direct toxicity to pathogens $(15,42)$, induction of systemic resistance (15), stimulating beneficial organisms (2), or inactivation of toxins produced by pathogens (35). Bowers and Locke (3) proposed that synthetic cinnamon oil (30\% cinnamaldehyde) may not reduce pathogen populations directly but, instead, may enhance the activity of beneficial organisms. In contrast, cinnamon oil directly affected $R$. oryzae-sativae by inhibiting vegetative growth and sclerotia germination in this study. It was probably because the major chemical constituent in cinnamon leaf oil used in this study was eugenal (34), whereas the active ingredient of cinnamon oil in the other study was different. However, whether cinnamon leaf oil could also induce systemic resistance in rice or inactivate a toxin produced by $R$. oryzae-sativae was still unknown.

The impacts of essential oils on humans and the environment have been reviewed (14). The toxicity of eugenal based on 96 h- $\mathrm{LC}_{50}$ is about 1,500 times less toxic than pyrethrum, a botanical insecticide, and 15,000 times less toxic than azinphosmethyl, an organophosphate insecticide $(14,37)$. Essential oil constituents are degradable in water and soil (24) and the residues of essential oil-based pesticides on crops should not be harmful to humans (14). Some plant essential oils may help prevent cancer in humans (26), reduce cholesterol $(6,7)$, have anti-inflammatory properties (38), and act against human foodborne pathogens, including Escherichia coli $\mathrm{O} 157$ and Listeria monocytogenes (29).

In this research, cinnamon oil showed potential for the control of aggregate sheath spot on rice and may be an alternative to synthetic fungicides for organic rice growers. However, a relatively high rate of cinnamon oil was necessary to control aggregate sheath spot. At a concentration of $62.5 \%$ cinnamon oil, approximately $0.625 \mathrm{ml} /$ pot or $1.3 \mu \mathrm{l} / \mathrm{cm}^{2}\left(13 \mathrm{ml} / \mathrm{m}^{2}\right)$ was required to reduce lesion expansion by $R$. oryzae-sativae. This amount is about 150 times higher than the recommended rate of azoxystrobin (40). Temperature, humidity, rainfall, and surface areas of rice fields may influence the degradation rate and evaporation rate of cinnamon oil in the field. These factors, which vary by geographic region, may affect the efficacy of cinnamon oil, the rate and frequency of its application, and cost. Moreover, cinnamon oil would have to be used with caution because high concentrations were phytotoxic. Future research should include study 
Table 5. Effect of cinnamon oil treatments on disease severity caused by Rhizoctonia oryzae-sativae isolate $3 \mathrm{~B}$ and plant dry weight of two rice cultivars (second greenhouse experiment) ${ }^{\mathrm{v}}$

\begin{tabular}{|c|c|c|c|c|c|c|}
\hline \multirow[b]{2}{*}{ Cultivar, isolate } & \multirow[b]{2}{*}{ Treatment $^{x}$} & \multicolumn{3}{|c|}{ Mean of lesion length $(\mathrm{cm})^{\mathrm{w}}$} & \multirow[b]{2}{*}{ Scores $^{y}$} & \multirow[b]{2}{*}{ Dry weight $(g)^{\mathrm{z}}$} \\
\hline & & 2 weeks & 3 weeks & 4 weeks & & \\
\hline \multicolumn{7}{|l|}{ M-205 } \\
\hline \multirow[t]{4}{*}{$3 \mathrm{~B}$} & No oil & 2.64 & 3.53 & 4.51 & $0.54 \mathrm{a}$ & $21.94 \mathrm{a}$ \\
\hline & Control & 2.53 & 3.21 & 3.65 & $0.47 \mathrm{a}$ & $22.81 \mathrm{a}$ \\
\hline & $37.5 \%$ & 1.73 & 2.14 & 2.85 & $0.34 \mathrm{ab}$ & $21.88 \mathrm{a}$ \\
\hline & $62.5 \%$ & 0.80 & 0.83 & 0.93 & $0.13 \mathrm{~b}$ & $21.38 \mathrm{a}$ \\
\hline \multirow[t]{4}{*}{ Noninoculated } & No oil & $\ldots$ & $\ldots$ & $\ldots$ & $\ldots$ & $24.94 \mathrm{a}$ \\
\hline & Control & $\ldots$ & $\ldots$ & $\ldots$ & $\ldots$ & $22.75 \mathrm{a}$ \\
\hline & $37.5 \%$ & $\ldots$ & $\ldots$ & $\ldots$ & $\ldots$ & $22.44 \mathrm{a}$ \\
\hline & $62.5 \%$ & $\ldots$ & $\ldots$ & $\ldots$ & $\ldots$ & $22.50 \mathrm{a}$ \\
\hline \multicolumn{7}{|l|}{ M-206 } \\
\hline \multirow[t]{4}{*}{$3 \mathrm{~B}$} & No oil & 1.78 & 2.49 & 2.78 & $0.35 \mathrm{a}$ & $23.44 \mathrm{a}$ \\
\hline & Control & 1.73 & 1.98 & 2.14 & $0.29 \mathrm{a}$ & $23.88 \mathrm{a}$ \\
\hline & $37.5 \%$ & 0.21 & 0.36 & 0.39 & $0.05 \mathrm{~b}$ & $24.75 \mathrm{a}$ \\
\hline & $62.5 \%$ & 0.68 & 0.73 & 0.90 & $0.12 \mathrm{~b}$ & $22.94 \mathrm{a}$ \\
\hline \multirow[t]{4}{*}{ Noninoculated } & No oil & $\ldots$ & $\ldots$ & $\ldots$ & $\ldots$ & $24.94 \mathrm{a}$ \\
\hline & Control & $\ldots$ & $\ldots$ & $\ldots$ & $\ldots$ & $24.88 \mathrm{a}$ \\
\hline & $37.5 \%$ & $\ldots$ & $\ldots$ & $\ldots$ & $\ldots$ & $24.69 \mathrm{a}$ \\
\hline & $62.5 \%$ & $\ldots$ & $\ldots$ & $\ldots$ & $\ldots$ & $23.69 \mathrm{a}$ \\
\hline
\end{tabular}

${ }^{v}$ Within each cultivar and each $R$. oryzae-sativae isolate, means in the same column followed by the same letter are not significantly different at $\alpha=0.05$ according to Tukey-Kramer HSD test.

${ }^{w}$ Length of the longest lesion of each rice plant was recorded weekly for 3 weeks $(2,3$, and 4 weeks after inoculation).

${ }^{x}$ Four cinnamon oil treatments were no oil, $1 \mathrm{ml}$ of vegetable oil but no cinnamon oil (control), $1 \mathrm{ml}$ of $37.5 \%$ cinnamon oil, and $1 \mathrm{ml}$ of $62.5 \%$ cinnamon oil.

y Canonical scores were calculated from lesion length data by repeated measures in multivariate analysis of variance procedure (32).

z Aboveground.

in the field and the potential of cinnamon oil to control a wide range of rice diseases.

\section{ACKNOWLEDGMENTS}

We thank the Royal Thai Government for financial support to P. Chaijuckam, C. A. Greer for rice seed, and R. Webster and D. Rizzo for helpful suggestions.

\section{LITERATURE CITED}

1. Banerjee, S., Bhattacharya, I., and Mukherjee, N. 1989. Sensitivity of three sclerotial rice pathogens to plant oils. Int. Rice Res. Newsl. $14: 23$.

2. Bowers, J. H., and Locke, J. C. 2000. Effect of botanical extracts on the population density of Fusarium oxysporum in soil and control of Fusarium wilt in the greenhouse. Plant Dis. 84:300-305.

3. Bowers, J. H., and Locke, J. C. 2004. Effect of formulated plant extracts and oils on population density of Phytophthora nicotianae in soil and control of Phytophthora blight in the greenhouse. Plant Dis. 88:11-16.

4. Cedeno, L., Nass, H., Carrero, C., Cardona, R., Rodriguez, H., and Aleman, L. 1998. Rhizoctonia oryzae-sativae, agent of the aggregated stain of rice in Venezuela. Interciencia 23:248251.

5. Christian, E. J., and Goggi, A. S. 2008. Aromatic plant oils as fungicide for organic corn production. Crop Sci. 48:1941-1951.

6. Ellegard, L., Andersson, H., and Bosaeus, I. 2005. Rapeseed oil, olive oil, plant sterols, and cholesterol metabolism: an ileostomy study. Eur. J. Clin. Nutr. 59:1374-1378.

7. Elson, C. E., Underbakke, G. L., Hanson, P., Shrago, E., Wainberg, R. H., and Qureshi, A. A. 1989. Impact of lemongrass oil an essential oil on serum cholesterol. Lipids 24:677-679.

8. El-Zemity, S. R., Radwan, M. A., Mohamed, S. A. E.-M., and Sherby, S. M. 2008. Antibacterial screening of some essential oils, monoterpenoids and novel N-methyl carbamates based on monoterpenoids against Agrobacterium tumefaciens and Erwinia caro- tovora. Arch. Phytopathol. Plant Prot. 41:451461.

9. Gunnell, P. S. 1992. Aggregate sheath spot. Pages 24-25 in: Compendium of Rice Diseases. R. K. Webster and P. S. Gunnell, eds. American Phytopathological Society, St. Paul, $\mathrm{MN}$.

10. Gunnell, P. S., and Webster, R. K. 1984. Aggregate sheath spot of rice in California. Plant Dis. 68:529-531.

11. Gunnell, P. S., and Webster, R. K. 1985. The effect of cultural practices on aggregate sheath spot of rice in California. (Abstr.) Phytopathology 75:1340.

12. Gunnell, P. S., and Webster, R. K. 1987. Ceratobasidium oryzae-sativae sp. nov., the teleomorph of Rhizoctonia oryzae-sativae and Ceratobasidium setariae comb.nov., the probable teleomorph of Rhizoctonia fumigata comb. nov. Mycologia 79:731-736.

13. Handique, A. K., and Singh, H. B. 1990. Antifungal action of lemongrass oil on some soilborne plant pathogens. Indian Perfum. 34:232234.

14. Isman, M. B. 2000. Plant essential oils for pest and disease management. Crop Prot. 19:603608.

15. Kagale, S., Marimuthu, T., Thayumanavan, B., Nandakumar, R., and Samiyappan, R. 2004. Antimicrobial activity and induction of systemic resistance in rice by leaf extract of $\mathrm{Da}$ tura metel against Rhizoctonia solani and Xanthomonas oryzae pv. oryzae. Physiol. Mol. Plant Pathol. 65:91-100.

16. Kishore, G. K., Pande, S., and Harish, S. 2007. Evaluation of essential oils and their components for broad-spectrum antifungal activity and control of late leaf spot and crown rot diseases in peanut. Plant Dis. 91:375-379.

17. Kong, J.-O., Lee, S.-M., Moon, Y.-S., Lee, S.G., and Ahn, Y.-J. 2007. Nematicidal activity of cassia and cinnamon oil compounds and related compounds toward Bursaphelenchus xylophilus (Nematoda: Parasitaphelenchidae). J. Nematol. 39:31-36.

18. Lanoiselet, V. L., Cother, E. J., Ash, G. J., and Harper, J. D. I. 2005. Yield loss in rice caused by Rhizoctonia oryzae and R. oryzae-sativae in Australia. Australas. Plant Pathol. 34:175-179.

19. Lanoiselet, V. M., Ash, G. J., Cother, E. J., Priest, M. J., and Watson, A. 2001. First report of Waitea circinata causing sheath spot and Rhizoctonia oryzae-sativae causing aggregate sheath spot on rice in south-eastern Australia. Australas. Plant Pathol. 30:369-370.

20. Lanoiselet, V. M., Cother, E. J., and Ash, G. J. 2007. Aggregate sheath spot and sheath spot of rice. Crop Prot. 26:799-808.

21. Lanoiselet, V. M., Cother, E. J., Ash, G. J., Hind-Lanoiselet, T. L., Murray, G. M., and Harper, J. D. I. 2005. Prevalence and survival, with emphasis on stubble burning, of Rhizoctonia spp., causal agents of sheath diseases of rice in Australia. Australas. Plant Pathol. 34:135-142.

22. Lee, E.-J., Kim, J.-R., Choi, D.-R., and Ahn, Y.-J. 2008. Toxicity of cassia and cinnamon oil compounds and cinnamaldehyde-related compounds to Sitophilus oryzae (Coleoptera: Curculionidae). J. Econ. Entomol. 101:1960-1966.

23. Miller, T. C., and Webster, R. K. 2001. Soil sampling techniques for determining the effect of cultural practices on Rhizoctonia oryzae sativae inoculum in rice field soils. Plant Dis. 85:967-972.

24. Misra, G., and Pavlostathis, S. G. 1997. Biodegradation kinetics of monoterpenes in liquid and soil-slurry systems. Appl. Microbiol. Biotechnol. 47:572-577.

25. Mordue, J. E. M. 1974. Rhizoctonia oryzaesativae. CMI (Commonw. Mycol. Inst.) Descr. Pathog. Fungi Bact. No. 409.

26. Murakami, A., Ohigashi, H., and Koshimizu, K. 1996. Anti-tumor promotion with food phytochemicals: a strategy for cancer chemoprevention. Biosci. Biotechnol. Biochem. 60:1-8.

27. Oh, B. Y., and Kim, J. H. 1988. Development feasibility of water-floating fungicide formulation for the control of sheath blight caused by Rhizoctonia solani in rice. Agric. Chem. Biotechnol. 31:226-233.

28. Oliveira, J. V., and Vendramim, J. D. 1999 Repellency of essential oils and powders from plants on adults of Zabrotes subfasciatus (Boh.) (Coleoptera: Bruchidae) on bean seeds. An. Soc. Entomol. Bras. 28:549-555.

29. Oussalah, M., Caillet, S., and Lacroix, M. 2006. Mechanism of action of Spanish oregano, Chinese cinnamon, and savory essential oils against cell membranes and walls of $E s$ cherichia coli $\mathrm{O} 157: \mathrm{H} 7$ and Listeria monocytogenes. J. Food Prot. 69:1046-1055.

30. Paranagama, P. A., Abeysekera, K. H. T., Abeywickrama, K., and Nugaliyadde, L. 2003. Fungicidal and anti-aflatoxigenic effects of the essential oil of Cymbopogon citratus (DC.) Stapf. (lemongrass) against Aspergillus flavus Link. isolated from stored rice. Lett. Appl. Microbiol. 37:86-90.

31. Patkar, K. L., Usha, C. M., Shetty, H. S., Paster, N., and Lacey, J. 1994. Effects of spice oil treatment of rice on moulding and mycotoxin contamination. Crop Prot. 13:519-524.

32. Proust, M. 2007. JMP Release 7: Statistics and Graphics Guide. SAS Institute Inc., Cary, NC.

33. Rahimian, H. 1989. Occurrence of aggregate sheath spot of rice in Iran. J. Phytopathol. 125:41-46.

34. Ranasinghe, L., Jayawardena, B., and Abeywickrama, K. 2002. Fungicidal activity of essential oils of Cinnamomum zeylanicum (L.) and Syzygium aromaticum (L.) Merr et L. M. Perry against crown rot and anthracnose pathogens isolated from banana. Lett. Appl. Microbiol. 35:208-211.

35. Shanmugam, V., Raguchander, T., Balasubramanian, P., and Samiyappan, R. 2001. Inactivation of Rhizoctonia solani toxin by a putative alpha-glucosidase from coconut leaves for control of sheath blight disease in rice. World J. Microbiol. Biotechnol. 17:545-552. 
36. Singh, H. B., and Singh, U. P. 1980. Inhibition of growth and sclerotium formation in Rhizoctonia solani by garlic oil. Mycologia 72:10221025.

37. Stroh, J., Wan, M. T., Isman, M. B., and Moul, D. J. 1998. Evaluation of acute toxicity to juvenile Pacific coho salmon and rainbow trout of some plant essential oils, a formulated product, and the carrier. Bull. Environ. Contam. Toxicol. 60:923-930.

38. Tung, Y.-T., Chua, M.-T., Wang, S.-Y., and
Chang, S.-T. 2008. Anti-inflammation activities of essential oil and its constituents from indigenous cinnamon (Cinnamomum osmophloeum) twigs. Bioresour. Technol. 99:3908-3913.

39. Velluti, A., Sanchis, V., Ramos, A. J., Egido, J., and Marin, S. 2003. Inhibitory effect of cinnamon, clove, lemongrass, oregano and palmarose essential oils on growth and fumonisin B1 production by Fusarium proliferatum in maize grain. Int. J. Food Microbiol. 89:145-154.

40. Webster, R. K., and Greer, C. A. 2004. Aggre- gate sheath spot of rice. UC IMP Pest Mangaement Guidelines: Rice. UC ANR Publ. 3465. University of California, Davis.

41. Webster, R. K., and Gunnell, P. S. 1992. Compendium of Rice Diseases. American Phytopathological Society, St. Paul, MN.

42. Wilson, C. L., Solar, J. M., Ghaouth, A. E., and Wisniewski, M. E. 1997. Rapid evaluation of plant extracts and essential oils for antifungal activity against Botrytis cinerea. Plant Dis. 81:204-210. 